\title{
The effect of hydrolysis duration on the antibacterial activity of swamp eel head protein hydrolysate produced by papain against histamine-producing bacteria
}

\author{
Witya Hafifani ${ }^{1}$, Indun D. Puspita ${ }^{1}$, and Masagus M. P. Putra ${ }^{1, *}$ \\ ${ }^{1}$ Fish Product Technology, Department of Fisheries, Faculty of Agriculture, Universitas Gadjah \\ Mada, $55281 \mathrm{Jl}$. Flora Gedung A4, Bulaksumur, Yogyakarta, Indonesia
}

\begin{abstract}
Swamp eel (Monopterus albus) processing produced byproducts such as heads that possess a high protein, carbohydrate, lipid, and energies content. Swamp eel heads were hydrolyzed (SEHPH) and tested for their antibacterial activity against histamine-producing bacteria (HPB) to explore the potency. The hydrolysis was conducted by a commercial papain enzyme PAYA (concentration 4\%) with various hydrolysis times $(0,60$, 120 , and 180 minutes) at $60^{\circ} \mathrm{C}$ with $\mathrm{pH} 5$. The results indicated that increasing hydrolysis time increased solubility and the degree of hydrolysis. The inhibitor concentration 50 test using microdilution of SEHPH inhibited $50 \%$ against three HPB named Citrobacter sp. (CK1), Klebsiella sp. (CK13), and Morganella morganii (TK7) at $20 \mathrm{mg} / \mathrm{ml}$. The optimum antibacterial activity test by disk diffusion method was formed by each minute of hydrolysis with the best inhibition zone to Klebsiella sp. (CK13). The macrodillution method showed the highest inhibition was produced by 180 hydrolyses with $45 \%$ on CK1, $54 \%$ on CK 13 , and $48 \%$ on TK7. These results indicated that SEHPH has potency as an antibacterial agent to reduce histamine-producing bacteria.
\end{abstract}

\section{Introduction}

Histamine $\left(\mathrm{C}_{5} \mathrm{H}_{9} \mathrm{~N}_{3}\right)$ is a biogenic amine causing food poisoning. Histamine is formed by the decarboxylation process of the histidine amino acid by histamine-producing bacteria (HPB). These bacteria generally live in seawater and naturally reside in the gills and digestive tract of fish. According to European Union Data, consumption of uncooked fish and fishery products is the leading cause of histamine poisoning. The histamine formation can be very fast, which is about $2-3$ hours at $20^{\circ} \mathrm{C}$. Histamine is usually found in food products, scombroid fish including tuna, mackerel, anchovy, sardines, bonito, marlin, herring, and mahi-mahi fish [1,5], fermented fish products including traditionally processed such as salted fish, pindang, and peda [2], wine, cheese, and meat products [3]. The cooking process in scombroid fish only removed HPB but could not release histamine that had formed [4]. In the case of fermented processed products, research showed that fermented food tends to have

\footnotetext{
* Corresponding author : primaputra@ugm.ac.id
} 
a higher histamine content than the fish itself [5]. HPB can quickly form if fish are not handled properly, causing disease for those who consume them. One way to prevent the formation of HPB is to use antibacterial compounds that can be obtained from fish protein hydrolysate (FPH).

Protein hydrolysate is a product of polypeptides, dipeptides, and amino acids, which can be produced from materials through protein hydrolysis. FPH can be hydrolyzed efficiently by using enzymatic hydrolysis because it makes high non-complex protein content. Papain is one of the proteolytic enzymes produced from papaya fruit latex or its leaves. It also has a commercial papain enzyme named "PAYA". Various types of peptides contained in the fish protein hydrolysate had some functions such as an anti-hypertensive [4], as anti-coagulant [5], as an anti-oxidant [4], as an anti-diabetic [6], as an anti-cancer [7], and as an antibacterial. Antibacterial is used explicitly for groups of harmful bacteria. The antibacterial mechanism damages cell walls, changing the membrane permeability, disrupting protein synthesis, and finally inhibiting en enzyme. Even though many studies found the relation of antibacterial activity in several types of fish protein hydrolysate, the study of swamp eel protein hydrolysate against HPB was rarely seen. Since there were many swamp eel farming in Indonesia, it is necessary to explore the antibacterial activity of swamp eel head protein hydrolysate. The hydrolysis was done with $4 \%$ papain according to [11] on various hydrolysis times with commercial papain enzyme "PAYA" at optimum $\mathrm{pH} 5$ and temperature $60^{\circ} \mathrm{C}$.

\section{Materials and methods}

\subsection{Material}

The primary material was a swamp eel head obtained from small-scale industries Citra Rasa, Godean, Yogyakarta. The charges were washed, placed in a plastic bag, and then stored in the refrigerator at $-10^{\circ} \mathrm{C}$ until further use. This study was conducted at Fishery Product Quality and Safety Laboratory, Universitas Gadjah Mada, Yogyakarta. The commercial papain enzyme "PAYA" with the activity of $1.053 \mathrm{U} / \mathrm{g}$ [12]. Three HPB was used for the determination of antibacterial activity: Morganella morganii (TK7), Citrobacter sp. (CK1), and Klebsialla sp. (CK13). Tryptic Soy Broth (TSB) and Tryptic Soy Agar (TSA) ware used for cultured bacteria.

\subsection{Hydrolysis of swamp eel head protein hydrolysate (SEHPH)}

This method was determined by using the method with slight modification [11]. Swamp eel head is first boiled to remove its natural enzyme. For each batch, minced swamp eel heads were mixed with aqua dest with a ratio of $1: 2(\mathrm{w} / \mathrm{v})$.-The mixture was blended with a papain enzyme of $4 \%$ concentration at $\mathrm{pH} 5$. The hydrolysis using water bath shaker with the temperature at $60^{\circ} \mathrm{C}$ for 0 minutes, 60 minutes, 120 minutes, and 180 minutes as treatments (SEHPH0, SEHPH60, SEHPH120, and SEHPH180). Then, the hydrolysis process was terminated by heating the sample $80^{\circ} \mathrm{C}$ for 10 mins to inactivate the papain activity. Swamp eel head protein hydrolysate was centrifuged for $20 \mathrm{mins}$ at $4^{\circ} \mathrm{C}$ and $3500 \mathrm{rpm}$, filtered and freeze-dried. The SEHPH was stored at $-20^{\circ} \mathrm{C}$ for the subsequent analysis.

\subsection{Water soluble protein content of SEHPH}

This assay used Coomassie brilliant blue G-250 at $595 \mathrm{~nm}$ to count the protein solubility and polypeptides within amino acids [13]. To construct a standard curve, this study used Bovine 
serum albumin (BSA). $500 \mu 1$ for each sample was added with $500 \mu 1$ Bradford Reagent and mixed gently by the vortex.

\subsection{Degree of hydrolysis}

The Bradford method was used to determine the percentage of solubilized protein in $10 \%$ trichloroacetic acid (TCA), and the Kjeldahl method for calculating the total protein content [14]. $500 \mu \mathrm{l}$ of protein hydrolysate were blended with $500 \mu \mathrm{l}$ of $20 \%$ of TCA. The mixture was incubated at 30 minutes and, after that, was centrifuged at $3000 \mathrm{rpm}$. The supernatant was added by $500 \mu \mathrm{l}$ Bradford reagent and mixed gently by vortexing. The sample's absorbance was $595 \mathrm{~nm}$ and followed the BSA curve standard. The degree of hydrolysis (DH) was estimated by:

$\mathrm{DH}(\%)=$ soluble protein in $10 \% \mathrm{TCA} /$ total protein content

\subsection{Antibacterial activity}

The antibacterial activity determined by using macrodillution method [15] and disk diffusion method [16] with HPB used were Morganella morganii (TK7), Citrobacter sp. (CK1), and Klebsialla $\mathrm{sp}$. (CK13). The inhibition concentration 50 ( $\left.\mathrm{IC}_{50}\right)$ was performed with various concentration which are 1.25, 2.5, 5, 10, and $20 \mathrm{mg} / \mathrm{ml}$ [17]. HPB (each Morganella morganii (TK7), Citrobacter sp. (CK1), and Klebsiella sp. (CK13)) suspension with OD 0.1 was added $20 \mu \mathrm{l}$ with kanamycin positive control. Tubes were vortexed and incubated for 24 hours at $37^{\circ} \mathrm{C}$. After incubation, the OD of each concentration has measured the absorbance at 600 $\mathrm{nm}$. The $\mathrm{IC}_{50}$ concentration was then used in the antibacterial activity assay.

The antibacterial activity was measured through the formula below:

$$
\% \text { inhibition }=\text { OD of negative control- OD of sample } / \text { OD of negative control }
$$

The macrodillution method was done according to [15] as follows: a $5 \mathrm{ml}$ TSB was prepared in a test tube, and 1\% (OD 0.1) of each HPB was added into the tube. The specific concentration of sterile SEHPH was then added into the tube, followed by incubation for 24 hours at $37^{\circ} \mathrm{C}$. After incubation, the OD of each test tube was measured at $600 \mathrm{~nm}$. The percent inhibition was measured as mentioned above.

Disk diffusion method was done according to [16]. The $50 \mu \mathrm{l}$ of each HPB OD 0.1 was spread into TSA with drigalski. $6 \mathrm{~mm}$ sterile paper disk which previously added $20 \mu \mathrm{l}$ of each treatment (negative control, positive control, SEHPH0, SEHPH60, SEHPH120, and SEHPH180) were placed on the agar. TSA plates were incubated for 24 hours at $37^{\circ} \mathrm{C}$. After 24 hours, the clear zone around the disk has measured the width of the antimicrobial inhibition zone according to the equation below:

$\%$ antibacterial activity $=$ diameter of inhibition zone - the disk diameter

\subsection{Statistical analysis}

The sample was conducted in triplicate, then represented as mean \pm standard deviation for each analysis. Post-hoc test (Tukey analysis) to discover the difference between treatments was used after determining the analysis of variance (ANOVA) as comparative statistical analysis $(p<0.05)$ using SPSS software. 


\section{Results}

The swamp ell (Monopterus albus) head is a by-product of swamp ell's small-scale industries in Yogyakarta as a non-edible portion. The head takes about $11.71 \%$ of total weight of the swamp ell. The head has the highest ash content, protein content, and carbohydrate $(1.86 \%$, $16.32 \%$, and $3.57 \%$, respectively). However, meat has significantly higher amounts of energy $(233.05 \mathrm{kal} / 100 \mathrm{~g}$, respectively). Proximate analyses of the swamp eel are shown in Table 1.

Table 1. Proximate analysis of swamp eel (Monopterus albus).

\begin{tabular}{|c|c|c|c|}
\hline Type of analysis & Head & Meat & Vicera \\
\hline Moisture (\%) & 62.60 & 65.54 & 67.21 \\
\hline Ash content (\%) & 1.86 & 1.69 & 1.22 \\
\hline $\begin{array}{c}\text { Protein content } \\
(\%)\end{array}$ & 16.32 & 14.13 & 14.19 \\
\hline Fat content (\%) & 15.45 & 16.80 & 16.87 \\
\hline Carbohydrate (\%) & 3.57 & 1.89 & 1.66 \\
\hline Energy (kal/100g) & 219.31 & 233.05 & 212.95 \\
\hline
\end{tabular}

\subsection{Water soluble protein content of SEHPH}

The optimum protein solubility is produced at a hydrolysis time of 120 minutes (SEHPH120) with $120 \pm 2.27 \mathrm{ppm}$ when the lower protein solubility hydrolysis time of 0 minutes was only $74.45 \pm 2.5 \mathrm{ppm}$. As described in Figure 1, the protein solubility of SEHPH increased with increasing the hydrolysis time from $74.45 \pm 2.5 \mathrm{ppm}$ at 0 minutes to $120.37 \pm 1.03 \mathrm{ppm}$ at 180 minutes.

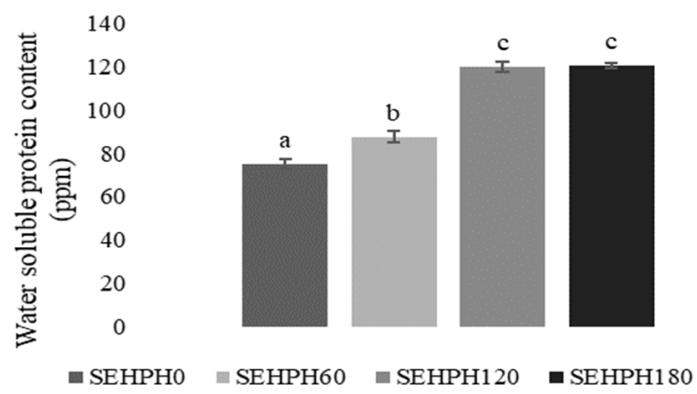

Fig. 1. Water soluble protein content of swamp eel protein hydrolysate (SEHPH) at a different time of hydrolysis (different alphabet at column mean there has significance at each other).

\subsection{Degree of hydrolysis}

In this research, 120 minutes of SEHPH (SEHPH120) hydrolysis gave the optimum values at $12.09 \pm 0.282 \%$. The results show that $\mathrm{DH}$ increased with increasing hydrolysis time from $7.82 \% \pm 0.14$ at 0 minutes to $12.54 \pm 0.37$ at 180 minutes. 120 minutes of hydrolysis doesn't have a significant difference from 180 minutes of hydrolysis. DH and protein solubility figures indicate that enzymatic hydrolysis will stop to a specific time of hydrolysis because enzymes have run out of protein bonds. 


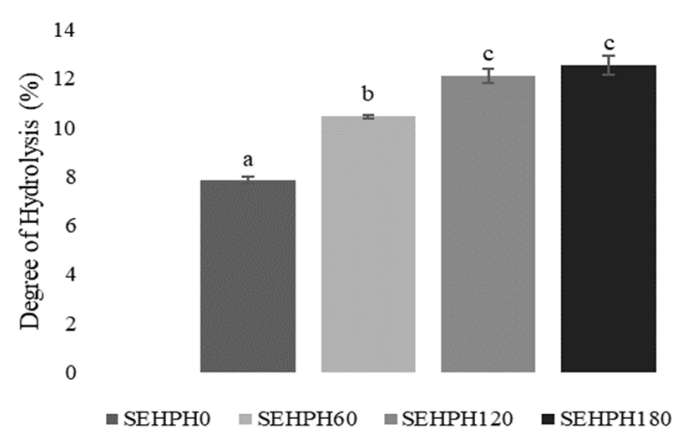

Fig. 2. Degree of hydrolysis of SEHPH at a different times of hydrolysis.

\subsection{Antibacterial activity}

The $\mathrm{IC}_{50}$ assay concluded that concentration $20 \mathrm{mg} / \mathrm{ml}$ showed $50 \%$ inhibition against Morganella morganii (TK7), Citrobacter sp. (CK1), and Klebsiella sp. (CK13). The 20 $\mathrm{mg} / \mathrm{ml}$ concentration was then used for every antibacterial activity. The results are shown in Figure 3. the SEHPH 0 minutes (SEHPH0) hydrolysis has a significant difference with other hydrolysis time with the macrodillution method. The macrodillution method showed the highest inhibition was produced by 180 hydrolyses with $45 \%$ on CK1, 54\% on CK13, and $48 \%$ on TK 7 .

Table 2. Antibacterial activity of SEHPH with disk diffusion method.

\begin{tabular}{|c|c|c|c|}
\hline Results & CK1 (mm) & $\begin{array}{c}\text { CK13(mm } \\
\text { ) }\end{array}$ & TK7(mm) \\
\hline $\begin{array}{c}\text { Negative } \\
\text { control }\end{array}$ & 0 & 0 & 0 \\
\hline Kanamycin & 15 & 19 & 14 \\
\hline SEHPH0 & $0 \pm 0$ & $0.33 \pm 0.57$ & $0 \pm 0$ \\
\hline SEHPH60 & $0.33 \pm 0.57$ & $1.33 \pm 1.52$ & $0.33 \pm 0.57$ \\
\hline SEHPH120 & $0.33 \pm 0.57$ & $1.33 \pm 0.57$ & $0.33 \pm 0.57$ \\
\hline SEHPH180 & $1 \pm 1$ & $1 \pm 0$ & $1 \pm 0$ \\
\hline
\end{tabular}

\section{CK1}

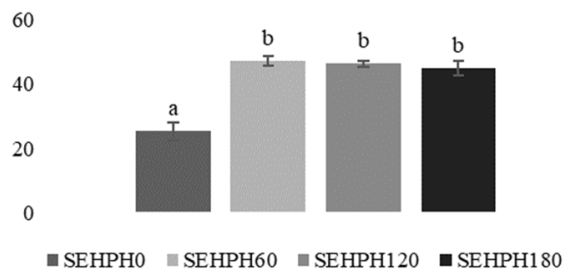

TK7

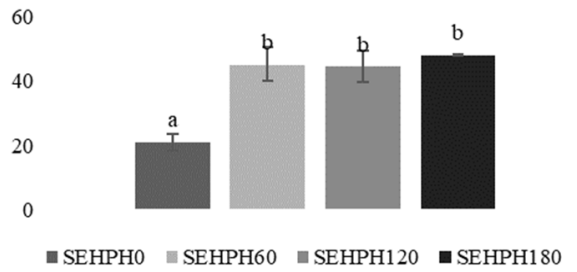




\section{CK13}

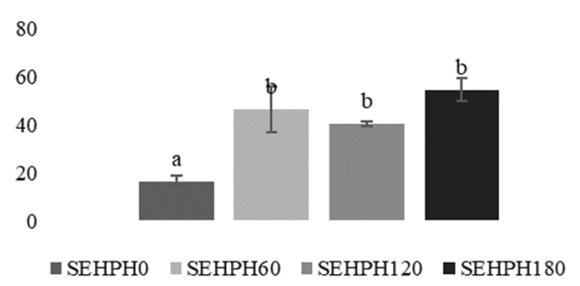

Fig. 3. SEHPH antibacterial activity with macrodillution method.

\section{Discussion}

\subsection{Hydrolysis of swamp eel head protein hydrolysate (SEHPH)}

The yield of swamp eel head protein hydrolysate (SEHPH) was accounted for about $2.83 \%$ of the total weight of the head sample used. Moreover, the result of hydrolysate also depends on the quality of samples and types of the enzyme were used. The SEHPH yield was lower than eel protein hydrolysate (EPH) at 6.97 [18] and the yield of freshwater carp (Catla catla) hydrolysate at $6.60 \%$ [19]. It can be caused by SEHPH having a different substrate ratio during hydrolysis compared to EPH and freshwater carp (Catla catla) hydrolysate. In the enzymatic process, the yield depends on the type of enzyme and substrate, hydrolysis conditions ( $\mathrm{pH}$, temperature, time, enzyme/substrate ratio), solvent ratio, and stirring speeds [20].

\subsection{Water-soluble protein content of SEHPH}

Fig.1. shows the protein solubility (ppm) of SEHPH obtained from commercial papain with various times of hydrolysis. Protein solubility is highly affected by protein concentration because when protein concentration increases, there is more chance for protein molecules to get closer to each other [21]. It will promote protein-protein interactions and make solubility decrease. Figure 1. proved that hydrolysis time had a significant effect on protein solubility. The protein solubility from tuna eye protein hydrolysate has $94.90 \pm 0.002 \%(\mathrm{p}<0.05)$ after 6-hour hydrolysis with papain enzyme (Merck) [22]. In another study, fish frame processing waste has $97.35 \%$ soluble protein by 60 minutes time of hydrolysis using papain enzyme (Carica papaya latex) [23].

\subsection{Degree of hydrolysis}

The degree of hydrolysis $(\mathrm{DH})$ is usually used to determine the percentage of peptide bonds cleaved and describe the properties of protein hydrolysate. Figure 2 shows the increases of $\mathrm{DH}$ with increasing hydrolysis time. The higher value of $\mathrm{DH}$, the more efficient the hydrolysis process, and the proteins were cleavage. But DH can depend on many factors, such as types of enzyme used for hydrolysis. PAYA, as a commercial enzyme, has low purity levels of papain, and it is a combination of the enzyme papain, salt, and sugar that is used for meat tenderizer products. Because of that, hydrolysates were hydrolysis with commercial enzyme has lower DH value than pure enzyme. Compared to other studies FPH, DH from SEHPH was still lower. The protein hydrolysate from Clarias batrachus has $53.48 \%$ after 180 minutes hydrolysis with papain enzyme (Rockford, IL, USA) [24] and protein 
hydrolysate Barramudi viscera were hydrolysis also by papain enzyme (Sigma) has $23.1 \pm$ $4.68 \%$ after 240 minutes [25].

\subsection{Antibacterial activity}

Peptides from SEHPH have antibacterial activity and much increased after hydrolysis. Hydrophobic amino acids were formed during hydrolysis would initiate peptide interaction with the surface of the bacteria then damage the bacteria membrane, membrane physiological disturbances such as cell biosynthesis, cell division, or translocation across the membrane to interact with the cytoplasm [26]. Antibacterial activity from A. lecanora protein hydrolysate effectively inhibited growth $S$. aureus and $E$. coli hydrolyzed with papain enzyme, and also can effectively inhibit Pseudomonas $s p$. and P. aeroginosa hydrolyzed with bromelain enzyme [27]. Other research reported that half-fin anchovy protein hydrolysate (HAHp) also could inhibit Gram-negative (E. coli, P. fluoroscens, Proteus vulgaris, and P. aeruginosa) and Gram-positive (S. aureus, Bacillus megaterium, and Sarcina lutea) because it reached 47. $71 \%$ hydrophobic amino acid as antibacterial peptides [28]. Antibacterial activity of peptides can be influenced by hydrophobicity and combination specific amino acids like histidine, arginine, alanine, valine, and leucine [29]

\section{Conclusion}

120 minutes of swamp eel head hydrolysis has more optimum protein solubility and degree of hydrolysis, $120 \pm 2.27 \mathrm{ppm}$, and $12.09 \pm 0.282 \%$. SEHPH also has antibacterial activity against HPB, with MIC reaching $\mathrm{IC}_{50}$ at $20 \mathrm{mg} / \mathrm{ml}$ concentration in SEHPH 180 minutes hydrolysis. SEHPH with 0 minutes hydrolysis time is significantly different from SEHPH 60 minutes hydrolysis, 120 minutes hydrolysis, and 180 minutes hydrolysis against HPB. Nevertheless, more research is needed to determine the amino acid composition in the Swamp eel head to prove its influence on antibacterial activity. The addition of a hydrolysis time of more than 180 minutes is also suggested.

\section{Acknowledgement}

This research was supported by research grant RTA Universitas Gadjah Mada No. 3143/UN.1.P.III/DIT-LIT/PT/2021.

\section{References}

1. P. Visciano, S. Maria, P. Antonello, Foods. 9, 12 (2020)

2. E.S. Heruwati, T. S. Suwarmo, U. S. Sinta, JPPI. 10 (2004)

3. M. Satomi, Food Sci. Tech. Resch. 22, 1 (2016)

4. V. Tortorella, M. Peppino, P. Mario, M. Assunta, P.T. Simona, C.Z. Maria, S. Annamaria, V. Mario, Hindawi, Publ. Corp. (2014)

5. O.C. Baste, L.L.M. Maria, S.P. Sonia, T.V.N. Maria, C.V.C. Maria Del. Licentech IntechOpen. (2019)

6. K. Korczek, T. Joanna, M. Wladyslaw. Czech, J. Food. Sci. 36, 195-207 (2018)

7. Y. Ren, H. Wu, F. Lai, X. Li, Y. Tang, Food. Resch. Inter. 64 (2014)

8. B. A. Kenhide, S. Poorva, Crit. Review. Food. Sci. Nutr. 60, 2 (2018)

9. R. Nurdiani, T. Vasilhevic, T.K. Singh, O.N. Donkor, Inter. Food. Resch. J. 24 (2017) 
10. Septiani, E.D. Nurcahya, I. Wijayanti. Indonesian J. Fish. Aqua. 13 (2017)

11. B.S.B. Utomo, D.S. Theresia, H.R. Herbert, Squal. Bull. Mar. \& Fish. Postharvest and Biotech. 9 (2014)

12. A.A. Darwis, A. Suryani, R. Peranglangin, S. Kusnaeni, JTIP. 2 (1995)

13. M.M. Bradford, Analytical Biochem. 72, 1-2 (1976)

14. M.P.C. Silvestre, H.A. Morais, V.D.M. Silva, M.R. Silva, J. Brazililan. Soc. Food. Nutr. 38, 3 (2013)

15. L.J.L. Esau, C.R. Rengel-Garcia, M. Hernandez-Duran, C.A. Colin-Castro, R. GarciaCintreras, R. Franco-Cendejas, J. Microbiol. Methods. 39, 362-445 (2019)

16. M. Marti, B. Frigols, A. Serrano-Aroca, J. Visualized Experiments. 138, 1-10 (2018)

17. M.D. Rocha, A. Ailen, C.B. Gryselle, M.E. Lopez-Caballero, C. Gomez-Guillen, M. Pilar, P. Carlos, J. Aqua. Food Product Tech. 27 (2018)

18. N.R.A. Halim, N.M. Sarbon, Intl. Food Research J. 24, 4 (2016)

19. K. Elavarasan, K. Naveen, V.B.A. Shamasundar, J. Food Process and Preservation 38, 3 (2014)

20. O.L. Awuor, E.K. Muge, B. Mbatia, F. J. M. Ind. Chem. 3 (2017)

21. J.K. Lee, Thesis, Minnesota (US) : University of Minnesota, (2011)

22. D. Mutaminah. B. Ibrahim, W. Trilaksmi, JPHPI. 21, 3 (2018)

23. P.G. Gajanan. E. Krishnamoorthy, A.S. Bangalore, Environ. Sci. Pollut. Res. 23, 2490124911 (2016)

24. M.S.M. Seniman, M.Y. Salma, S.B. Abdul, AIP Conf. Proc. 1614, 3 (2014)

25. T. Nurhayati, E. Salamah, Cholifah, Roni N., JPHPI. 17, 1 (2014)

26. P. Lestari, Suyata, IOP Conf. Series : Marterial Science and Engineering 509, 1 (2019)

27. R. Ghanbari, E. Afshin, A H. Azizah, I. Amin, S. Nazamid, Int. J. Mol. Sci. 13, 12 (2012)

28. R. Song, W. Rongbian, Z. Bin, W. Dongfeng, Food Biopro. Technol. 5 (2012)

29. N. Nedjar-Arroume, V. Dubois-Delval, A.E. Yaba, J. Traisnel, F. Kriel, P. Mary, M. Kouach, G. Briand, D. Guillochon, Peptides 29 (2008) 